\section{The function of Xenopus Bloom's syndrome protein homolog (xBLM) in DNA replication}

\author{
Shuren Liao, Jeanine Graham, and Hong Yan ${ }^{1}$ \\ Fox Chase Cancer Center, Philadelphia, Pennsylvania 19111, \\ USA
}

The Bloom's syndrome gene (BLM) plays a pivotal role in the maintenance of genomic stability in somatic cells. It encodes a DNA helicase (BLM) of the RecQ family, but the exact function of BLM remains elusive. To study this question, we have cloned the BLM homolog of the frog Xenopus laevis (xBLM) and have raised antibodies to it. Immunodepletion of $\mathrm{xBLM}$ from a Xenopus egg extract severely inhibits the replication of DNA in reconstituted nuclei. Moreover, the inhibition can be rescued by the addition of the recombinant XBLM protein. These results provide the first direct evidence that BLM plays an important role in DNA replication, suggesting that Bloom's syndrome may be the consequence of defective DNA replication.

Received May 30, 2000; revised version accepted September 5, 2000.

Bloom's syndrome (BS) is associated with cancer, immunodeficiency, proportional dwarfism, and sun-sensitive facial erythema (German and Ellis 1998). Despite its rarity, BS is of great significance in biomedical research because it displays dramatically the consequences of excessive genomic instability. In BS cells chromosome gaps, breakages, and rearrangements are easily observed. Interchanges between homologous chromosomes and, in particular, between sister chromatids are greatly increased (Ray and German 1983). Surprisingly, BS cells are not defective in the known DNA repair pathways (Friedberg et al. 1979). Instead, they show a retarded rate of nascent DNA chain elongation (Hand and German 1975) and accumulate abnormal replication intermediates (Lonn et al. 1990). The gene mutated in BS encodes a DNA helicase (BLM) of the RecQ family (Ellis et al. 1995), and the helicase activity has been confirmed in vitro with the recombinant protein (Karow et al. 1997). BLM is localized in the nucleus at discrete foci (identical to promyelocytic leukemia protein bodies), diffused patches, nucleoli in $S$ phase cells, and telomeres in telomerase-negative tumor cells (Ishov et al. 1999; Neff et al. 1999; Zhong et al. 1999; Yankiwski et al. 2000). It

[Key Words: Bloom's syndrome; DNA replication; Xenopus laevis; RecQ; Werner's syndrome; FFA-1]

${ }^{1}$ Corresponding author.

E-MAIL Hong_Yan@fccc.edu; FAX (215) 728-3565.

Article and publication are at www.genesdev.org/cgi/doi/10.1101/ gad. 822400 . has been reported to interact with topoisomerase III (Johnson et al. 2000; Wu et al. 2000) and Brcal (Wang et al. 2000). Despite this progress, the function of BLM remains elusive.

The phenotypes of BS cells imply that BLM may be involved in DNA replication, but this interpretation is complicated by the very nature of genomic instability in BS cells. The replication defect may be an indirect effect of defects in other processes such as DNA repair, recombination, or even transcription, or it may result from secondary mutations in genes other than BLM. To definitively examine the role of BLM in DNA replication, we have used the interphase extract of Xenopus eggs as the model system. In this extract, a DNA substrate, such as demembranated sperm chromatin or purified lambda DNA, induces nuclear formation around itself, and the DNA within the nuclei is replicated once. It is the only cell-free system that can replicate genomic DNA in a semiconservative manner (Lohka and Masui 1983; Newport 1987). By immunodepleting a protein from the extract, one can conclusively determine whether it is important for DNA replication. We have cloned and expressed the Xenopus homolog of BLM and have raised specific antibodies to it. We have found that immunodepletion of $x B L M$ from the egg extract severely inhibits the replication of DNA in the reconstituted nuclei. Moreover, the inhibition can be restored by the addition of the recombinant $x B L M$ protein. These results provide the first direct biochemical evidence that BLM is involved in DNA replication. They also suggest that the clinical and cellular phenotypes of BS may be associated with a defect in DNA replication.

\section{Results}

We first cloned the helicase domain of the Xenopus BLM from an oocyte cDNA library by PCR with degenerate primers corresponding to two stretches of amino acids conserved among RecQ helicase family members. The two ends were subsequently cloned by $5^{\prime}$ and $3^{\prime}$ random amplification of cDNA ends (RACE) reactions. The complete sequence encodes an open reading frame (ORF) of 1367 amino acids (aa), slightly smaller than that of the human $B L M$ (1417 aa) and mouse BLM (1416 aa). The predicted molecular weight is $153 \mathrm{kD}$ and the $\mathrm{pI}$ value is 8.68. $x B L M$ and hBLM share extensive homology throughout the ORF, especially in the second half (Fig. 1). The overall amino acid identity is $50 \%$, and the total similarity is $64 \%$.

The xBLM protein was then expressed in Escherichia coli with a His tag at the carboxyl terminus and purified on a nickel affinity column. The recombinant protein ran at $160 \mathrm{kD}$ on SDS-PAGE (Fig. 2A), slightly larger than the predicted molecular weight of $154 \mathrm{kD}$ (including the His tag). It showed DNA helicase activity, and either ATP or dATP could drive the unwinding reaction (Fig. 2B). To study the function of xBLM, we prepared 
BLM 1 MAAVPQNNLQEQLERHSARTLNNKLSLSKPKFSGFTFKKKTSSDNNVSVTNVSVAKTPVLRNKDVNVTEDFSFSEPLPNTTNOORVKDFFKNAPAGQETQRGGSKSLLPDFLQTPKEVVC 120 XBLM 1 MAALPQNNLQKQLELFSAKGTSNKLSLQKTKSSVFTFKKKCSP-NVSASTGFIPFQQHVLKDKNVNVKQDG-THTALPKATERNKINCFFT--PVYTKSGQPPQVVALRDHVHG-----N 111

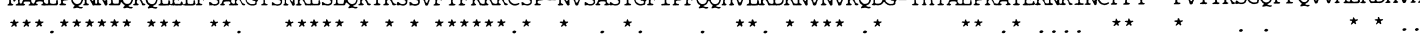

BLM 121 TTQNTPTVKKSRDTALKKLEFSSSPDSLSTINDWDDMDDFDTSETSKSFVTPPQSHFVRVSTAQKSKKGKRNFFKAQLYTTNTVKTDLPPPSSESEQIDLTEEQKDDSEWLSSDVICIDD 240 XBLM 112 DSANKPPS--TEDAASKKTGINTSFGSVTSLEEWDDLDDFDTSVS------PPKSHAGKSG---KTPQKCKNTSPVASFKIQSISPEGP----TTEKHDCAKLLYDNN-EVASEPRKNLH 215

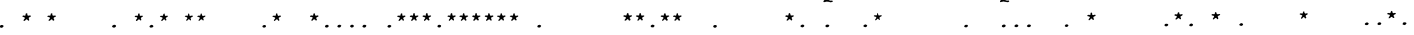

BLM 241 GPIAEVHINEDAQESDSLKTHLEDERDNSEKKKNLEEAELHSTEKVPCIEFDDDDYDTDFVPPSPEEIISASSSSSKCLSTLKDLDTSDRKEDVLSTSKDLLSKPEKMSMQELNPETSTD 360 XBLM 216 AKTAESPDQSLVCLASVEPTNLERHMCRNTDYLGTDDLEHDQETLSQVLIEEEDDCGPDFIPPSP----SDESLSS---PPVLKVISAQRKHKVSSLTDVNDCENTTDHLQGQSVSTSLD 328

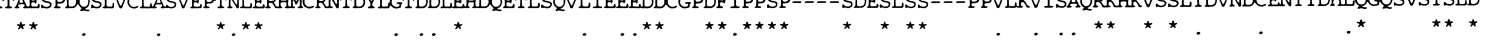

BLM 361 CDARQISLQQQLIHVMEHICKLIDTIPDDKLKLLDCGNELLQQRNIRRKLLTEVDFNKSDASLLGSLWRYRPDSLDGPMEGDSCPTGNSMKELNFSHLP-SNSVSPGDCLLTTTLGKTGF 479 xBLM 329 S----KVPSQLLTLMLEICDLVDKIPISELHVLSCGLDLKKKRDMRKRLLS----NDS-------VFRSSP-ADSSTVSLTSCTSSTQNRDFNVNAPKGAESLSGSSVSKVFKFNKLAV 431

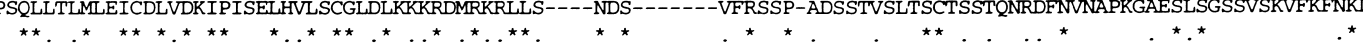

BLM 480 SATRKNLFERPLFNTHLQKSFVSSNWAETPRLGKK---NESSYFPGNVLTSTAVKD-QN-KHTASINDLERETQPSYDIDN-----FDIDDFDDDDDWEDIMHNLAASKSSTAAYQPIKEG 590 XBLM 432 HDIGTKESENSANSAPNFMEKIGNKTSFSFRAGGDSIMENSFNFHSSVLSNSQFNTPQNEKPISSSTCTRPYSQPIDDMDNPDLDFDIDNFDIED--LDDIHCLDSPAAPSVSSKNVPQY 549

BLM 591 RPIKSVSERLSSAKTDCLPVSSTAQNINFSESIQNYTDKSAQNLASRNLKHERFQSLSFPHTKEMMKIFHKKFGLHNFRTNQLEAINAALLGEDCFILMPTGGGKSLCYQLPACVSPGVT 710 xBLM 550 PTIR-------EAQIDSRNKEKNTRNNTGDTTNPSLLSDSLQKPQIENPAHERFRGFNFPHSKEMMKIFHKKFGLHRFRTNQLEAINARLCGEDCFILMPTGGGKSLCYQLPGCISPGVT 662

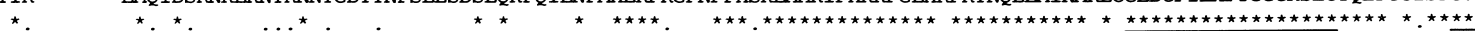

BLM 711 VVISPLRSLIVDQVQKLTSLDIPATYLTGDKTDSEATNIYLQLSKKDPIIKLLYVTPEKICASNRLISTLENLYERKLLARFVIDEAHCVSQWGHDFRQDYKRMNMLRQKFP--SVPVMA 828 XBLM 663 IVISPLRSLIVDQVOKLTSLDIPATYLTGDKTDAFAASTYLOLSKKDPIIKLLYVTTPEKVCASTRLISTMENLYEROLLARFVIDEAHCVSOWGHDFRPDYKRLNVI_APEVPWOSVPMMA 782

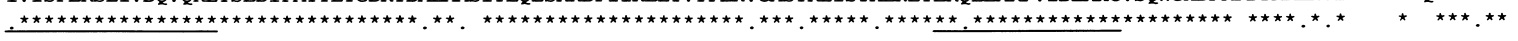
Ia II

BLM 829 LTATANPRVOKDILTOLKILRPOVFSMSFNRHNLKYYVLPKKPKKVAFDCLEWIRKHHPYDSGIIYCLSRRECDTMADTLORDGLAALAYHAGLSDSARDEVQQKWINQDGCQVICATIA 948 XBLM 783 LTATANPRVKKDILNQLKMTKPQIFTMSFNRDNLKYEVLPKKPKRVALDCVEWIKKHHPNDSGIIYCLSRHECDTMADTLQKEGLAALAYHAGLADSNRDYVQHKWINQDDCQVICATIA 902

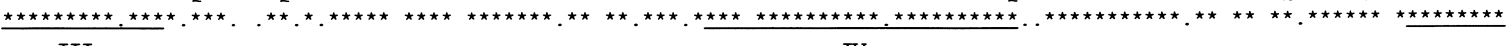

BLM 949 FGMGIDKPDVRFVIHASLPKSVEGYYQESGRAGRDGEISHCLLFYTYHDVTRLKRLIMMEKDGNHHTRETHFNNLYSMVHYCENITECRRIQLLAYFGENGFNPDFCKKHPDVSCDNCCK 1068 XBLM 903 FGMGIDKPDVRYVIHASLPKSVEGYYQESGRAGRDGETSHCLPFYSYHDVTRIRRLIQMEKDGNSHTKQTHFNNLYSMVHYCENVVECRRMQLLSYFGENNFNPNFCKEHTQVACDNCLG 1022

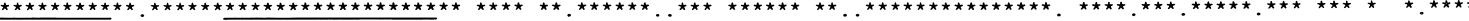
$\mathrm{V}$

BLM 1069 TKDYKTRDVTDDVKSIVRFVQEHSSSQGMRNIKHVGPSGRFTMNMLVDIFLGSKSAKIQSGIFGKGSAYSRHNAERLFKKLILDKILDEDLYINANDQAIAYVMLGNKAQTVLNGNLKVD 1188 xBLM 1023 KKNYKSRDVTDDVGNIVRFVQDNCSLVKDRGKGRSN-NTRLTLNMMVDIFLGSKSAKIQTGLFGKGAAYSRHNAERLFRKLVLDRIIDEELYITFNDQAVAYVKMGERAQAVLNGFLKVD 1141

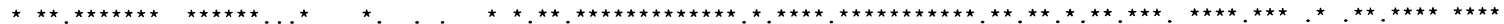

BLM 1189 FMETENSSSVKKQ-KALVAKVSQREEMVKKCLGELTEVCKSLGKVFGVHYFNIFNTVTLKKLLAESLSSDPEVLLQIDGVTEDKLEKYGAEVISVLQKYSEWTSPAEDSSPGISLSSSRGP 1307 XBLM 1142 FQDTESASSIRKOKASVVTNTSQREEMVKKCQAELTELCKRLGKIFGVHYFNIFNTATIRRIAESLSPEPEVLLQIDGVTEDKLDKYGAELIDVLOKYSEWTLPVEDICQKSGGPANVSA 1261

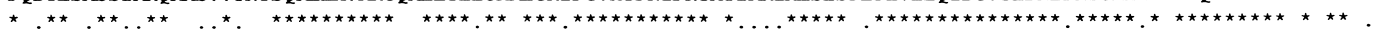

BLM 1308 GRSAAEELDEEIPVSSHYFASKTRNERKRKKMPASQRSKRRKTASSG--SKAKGG-SATCRKISSKTKSSSIIGSSSASHTSQATSGANSKLGIMAPPKP-INRPFLKPSYAFS 1417 xBLM 1262 RRYNSDHDDDESCDKSSYFSSNNKKGPKRKNSAYFGKSKKRKTGGDGQQSRSKNGNSSYARKNSTAKTSSSYISGS-------KTGADKRPGFMAPPMPQPNRRFLKPSYSMF 1367

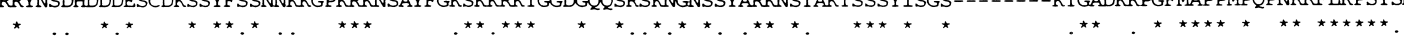

Figure 1. Sequence alignment of Xenopus and human BLM open reading frames. ClustalW in MacVector 6.5 was used for the alignment. (Asterisks) Identical amino acids; (periods) similar amino acids. The helicase motifs are underlined.

polyclonal antibodies against a glutathione $S$ transferase (GST) fusion protein containing the amino-terminal 173 amino acids of xBLM, a part of the protein not conserved among RecQ family members. Western analysis indicated that these antibodies consistently recognized a protein of about $160 \mathrm{kD}$ in the egg extracts (Fig. 2C). We believe this protein is the endogenous xBLM based on two observations: (1) Its size is similar to that of the recombinant xBLM-His protein; (2) both proteins are eluted from cation exchange columns at high salt concentrations (500-600 mM NaCl), a property consistent with the high pI value of xBLM (data not shown).

To investigate the role of XBLM in DNA replication, we performed a series of immunodepletion experiments. Interphase extracts were incubated with Affi-gel Protein A beads precoated with either anti-xBLM antibody or control antibody. This procedure effectively removed xBLM (>99\%) from the anti-xBLM antibody-depleted extract but not the mock-depleted extract (Fig. 2D). To assay for DNA replication, the extracts were then incubated with demembranated sperm chromatin in the pres- ence of $\left[{ }^{32} \mathrm{P}\right] \mathrm{dATP}$. Strikingly, DNA replication was severely inhibited (5-10-fold) in the xBLM-depleted extract (Fig. 3A). This effect was observed both with extracts reconstituted from frozen cytosol and membrane components and freshly made crude extracts. Moreover, replication was largely restored when the recombinant His-tagged $\mathrm{xBLM}$ protein was added back to the $\mathrm{xBLM}$ depleted extract, suggesting that the inhibition is due solely to the removal of XBLM rather than some other cross-reacting protein (Fig. 3B). In addition, as shown in Figure 3C, nuclear formation, which is required for DNA replication, was normal in the absence of xBLM, suggesting that the inhibition is not an indirect effect on nuclear formation. Collectively these observations strongly suggest that xBLM plays an important role in DNA replication in reconstituted nuclei.

DNA replication can be considered as two major steps: the unwinding of a double-stranded DNA template and the actual synthesis reaction on the resulting singlestranded DNA. To address at which of these steps xBLM functions, we determined the effect of xBLM depletion 


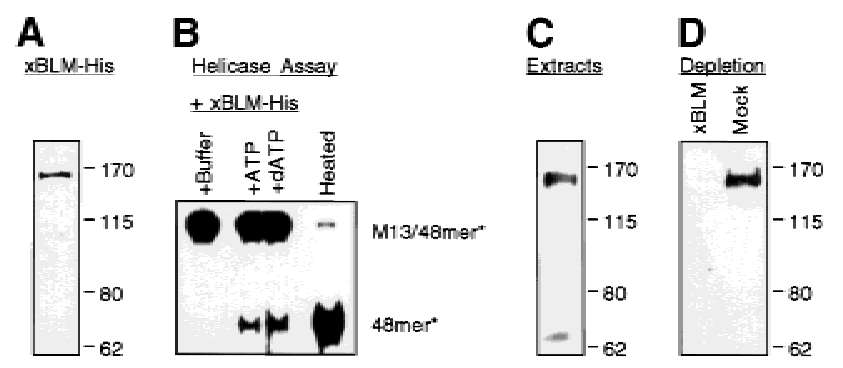

Figure 2. Characterization of xBLM protein. $(A)$ Coomassie blue staining of the purified His-tagged recombinant $\mathrm{xBLM}$ protein. $(B)$ Helicase activity of the recombinant xBLM. The substrate is a $5^{\prime}-{ }^{32} \mathrm{P}$-labeled $48 \mathrm{mer}$ oligonucleotide hybridized to m13mp18 single-stranded DNA. The purified xBLM protein was incubated with the substrate in the presence of either buffer alone or nucleotides (ATP or dATP). The right lane contains the heat-denatured substrate. The dissociated oligonucleotide was separated from $\mathrm{m} 13$ on $12 \%$ polyacrylamide gels. $(C)$ Western blot of interphase egg extracts $(2 \mu \mathrm{L})$ probed with the affinitypurified rabbit anti-xBLM antibody and detected by ECL (Amersham). The $160-\mathrm{kD}$ band is xBLM. The small band is not always detected, suggesting that it is a degradation product. $(D)$ Immunodepletion of xBLM from egg extracts. Supernatants 12 $\mu \mathrm{L})$ from the extracts that had been depleted with either antixBLM or control antibodies were analyzed by Western blot with the affinity-purified rabbit anti-xBLM antibody. Molecular markers are labeled as kilodaltons on the right side of panels $A$, $C$, and $D$.

on the replication of $\mathrm{m} 13$ single-stranded DNA in the extract. This reaction does not require the unwinding of a double-stranded DNA template but rather requires the recruitment of multiple replication proteins to synthesize the complementary strand (Mechali and Harland 1982). As shown in Figure 3D, m13 DNA replicated equally well in xBLM-depleted and control-depleted extracts, suggesting that xBLM functions not in the synthesis step but rather in the unwinding step. This conclusion is consistent with the DNA helicase activity of xBLM.

Although depletion of xBLM severely inhibited DNA synthesis in reconstituted nuclei, the inhibition was never complete. There are three likely explanations for the remaining DNA synthesis: (1) repair reaction; (2) incomplete depletion of $x B L M$; and (3) the presence of another functionally redundant protein(s). To differentiate replication from repair, we examined the sensitivity of the remaining DNA synthesis to the human $\mathrm{p} 21$ protein, which can specifically block DNA replication in Xenopus egg extracts by inhibiting Cdk2 kinase activity (Strausfeld et al. 1994; Jackson et al. 1995; Yan and Newport 1995). When p21 was added to a reaction with the xBLM-depleted extract, DNA synthesis was dramatically reduced to a level barely above background (Fig. 4A). These results suggest that the remaining DNA synthesis in the xBLM-depleted extract is still bona fide replication.

We then tested whether the remaining DNA synthesis is attributable to incomplete depletion of XBLM from the extract. Small amounts of untreated extract were added back to the xBLM-depleted extract to rescue DNA replication (recombinant xBLM was not used because the portion of properly folded protein could not be determined). Although we could detect XBLM in as little as $0.1 \mu \mathrm{L}$ of extract (data not shown), this amount ( $1 \%$ ) was insufficient to increase replication in a $10-\mu \mathrm{L}$ reaction (Fig. 4B). Because the depletion of xBLM was at least 99\% complete, these results suggest that the remaining DNA synthesis is not because of incomplete depletion.

The most likely explanation, therefore, is that some other protein may have an activity similar to (although much weaker than) that of xBLM and can partially compensate for the depletion of $\mathrm{xBLM}$. This explanation is consistent with the observation that neither human nor mouse BLM is essential. A good candidate for the redundant protein is another RecQ helicase family member, FFA-1 (focus forming activity 1), the Xenopus homolog of Werner's syndrome protein (WRN; Yan et al. 1998). FFA-1 also functions in DNA replication, but its depletion from the extract does not affect DNA replication because of the presence of a redundant protein /data not shown). We depleted egg extracts with either anti-FFA-1 antibody or anti-xBLM antibody or both antibodies together. As shown in Figure 4C, the two antibodies did not cross-react with each other. To our surprise, double depletion of FFA-1 and xBLM did not further reduce the

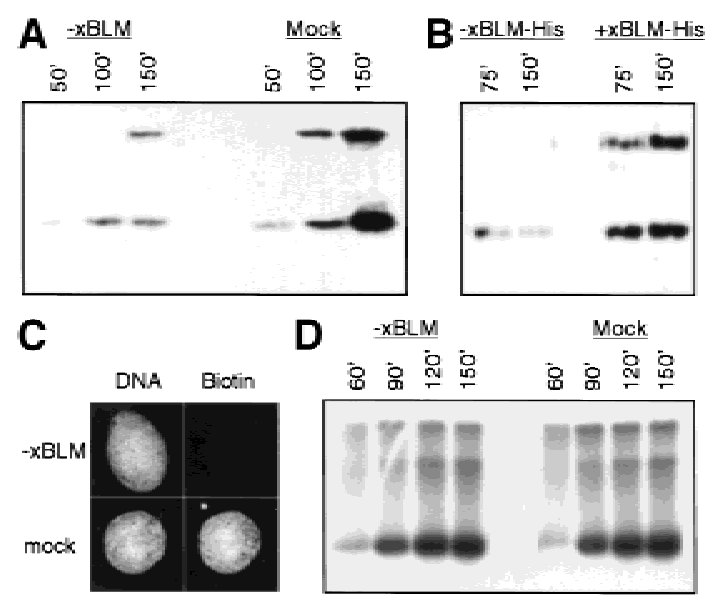

Figure 3. Effect of xBLM depletion on DNA replication in interphase extracts. The reactions were continuously labeled with $\left[{ }^{32} \mathrm{P}\right] \mathrm{dATP}$, and samples were taken at the times indicated. The replication products were separated by electrophoresis on agarose gels. (A) Inhibition of DNA replication within the nuclei reconstituted around sperm chromatin in the xBLM-depleted extract. (B) Rescue of DNA replication by the recombinant $\mathrm{xBLM}-$ His protein. The purified His-tagged xBLM protein was added to the xBLM-depleted extract at the start of the nuclear reconstitution reaction ( $4 \mathrm{ng} / \mu \mathrm{L}$ final concentration). (C) Effect of xBLM depletion on nuclear assembly. Nuclei were reformed in the depleted extracts in the presence of biotin-dCTP. The incorporated biotin-dCTP was detected with Streptavidin Texas Red by immunostaining. DNA was stained with Hoechst dye. (D) Effect of xBLM depletion on m13 single-stranded DNA replication. m13 DNA ( $5 \mathrm{ng} / \mu \mathrm{L}$ final concentration) was incubated with the depleted cytosol (no membrane) in the presence of $\left[{ }^{32} \mathrm{P}\right] \mathrm{dATP}$. 

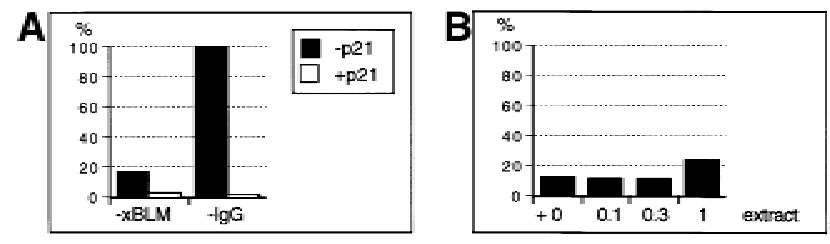

C
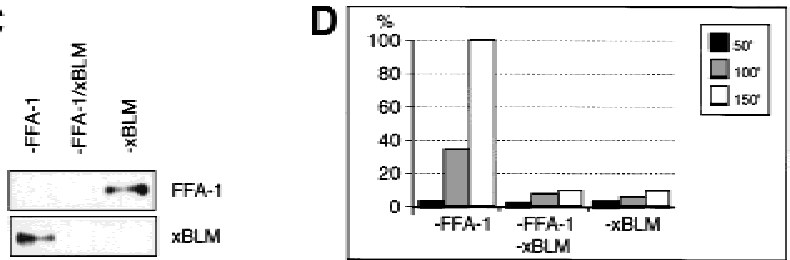

Figure 4. Analysis of residual DNA synthesis in nuclei reconstituted in xBLM-depleted extracts. (A) Inhibition of residual DNA synthesis by $\mathrm{p} 21$. Reactions with either xBLM antibodydepleted or rabbit IgG-depleted extracts in the presence $(0.4 \mu \mathrm{M})$ or absence of human p21 protein. $\left[{ }^{32} \mathrm{P}\right] \mathrm{dATP}$ incorporation of the IgG-depleted reaction with no p21 is set at $100 \%$. (B) Rescue of DNA replication. Reactions $(10 \mu \mathrm{L})$ containing xBLM-depleted extracts were supplemented with various amounts of untreated extracts (in $\mu \mathrm{L}$ ). Incorporation of $\left[{ }^{32} \mathrm{P}\right] \mathrm{dATP}$ is plotted as percentages of that of the IgG-depleted reaction. $(C)$ DNA replication in FFA-1 and xBLM single- or double-depleted extracts. (Left panel) Western analysis of the extracts that had been depleted with the indicated antibodies. Two blots were probed with affinity-purified rabbit anti-FFA-1 or anti-xBLM antibody. (Right panel) Incorporation of $\left[{ }^{32} \mathrm{P}\right] \mathrm{dATP}$ of the three depleted reactions plotted against that of the IgG-depleted reaction at 150 min.

residual DNA synthesis when compared with the single depletion of xBLM (Fig. 4D). These results suggest that the redundant partner for $x B L M$ is not FFA-1 but some other protein yet to be identified.

\section{Discussion}

We have shown that depletion of the Xenopus BLM homolog severely inhibits the replication of DNA in the reconstituted nuclei. Moreover, the inhibition can be reversed by the addition of the recombinant xBLM. Thus, it is the xBLM protein itself rather than some other codepleted protein that is required for efficient DNA replication. The depletion of XBLM, however, does not affect the replication of m13 single-stranded DNA, indicating that xBLM does not participate in DNA synthesis per se. This result, in combination with the helicase activity of $x B L M$, suggests that $x B L M$ is involved in the unwinding of double-stranded DNA template. Finally, we show that double depletion of XBLM and another RecQ family member, FFA-1, does not cause further reduction in the efficiency of DNA replication, suggesting that these two proteins are not redundant to each other. This result is consistent with the different clinical and cellular phenotypes of Bloom's syndrome and Werner's syndrome (German and Ellis 1998; Schellenberg et al. 1998).
The marked reduction in DNA replication in xBLMdepleted Xenopus egg extracts is in contrast to the mild defect in DNA replication in human BS cells. One likely explanation for this discrepancy is that different assays were used in the two cases. Xenopus eggs are programmed for rapid DNA synthesis with an S phase of only $10 \mathrm{~min}$, whereas somatic cells replicate DNA at a much lower rate with $\mathrm{S}$ phases of $>8 \mathrm{~h}$. As such the absence of xBLM may have a disproportional impact on our in vitro assay. Another explanation is that varying degrees of gene redundancy exist in different organisms. As support for this idea, null mutations of BLM cause embryonic lethality in mouse but not in human (Chester et al. 1998). It is possible that the redundant protein in Xenopus is poorly expressed or not very active in the unfertilized eggs. One way or the other, our experiments strongly suggest that xBLM plays an important role in DNA replication. A similar function in DNA replication for the human BLM protein may explain the replication defects and higher mutation rates of BS cells. Increased rates of recombination between homologous chromosomes and sister chromatids may be an indirect effect of abnormal replication.

Among the many potential functions suggested for the RecQ family of helicases, participation in DNA replication is emerging as a common theme. Mouse WRN protein copurifies with a large protein complex consisting of multiple replication proteins (Lebel et al. 1999). FFA-1, the Xenopus homolog of WRN, is involved in the assembly of replication foci (Yan et al. 1998). In the budding yeast Saccharomyces cerevisiae, double disruption of two helicase genes, Sgs1 (RecQ type) and Srs2 (non-RecQ type), blocks the cell cycle with an unreplicated genome (Lee et al. 1999). In the fission yeast Schizosaccharomyces pombe, cells carrying null mutations of the $R q h 1$ gene (RecQ type) are unable to recover from $S$ phase arrest (Stewart et al. 1997), and double mutants of Rqh1 and several replication elongation genes are synthetically lethal (Murray et al. 1997). Even in E. coli, RecQ, the prototype family member, participates in the RecF recombination pathway, which is critical for the reinitiation of DNA replication after UV irradiation (Courcelle and Hanawalt 1999). Further characterization of the exact roles these proteins play in DNA replication and how these roles evolve with genome complexity will provide more insights into how cells maintain their genome.

\section{Materials and methods}

Egg extract preparation and nuclei reconstitution

Crude interphase extracts and cytosol and membrane components derived from them were prepared following the procedure of Smythe and Newport (1991). Both crude extracts and fractionated components were used and found to be similar in the experiments of this study. They were collectively referred to as extracts unless otherwise specified. Nuclei were reconstituted at room temperature by mixing either crude extract ( $1 / 2$ of the final volume) or cytosol ( $1 / 3$ of the final volume) and membrane (1/10 of the final volume) with ATP-regeneration system $(2 \mathrm{mM}$ ATP, $20 \mathrm{mM}$ phosphocreatine, $50 \mu \mathrm{g} / \mathrm{mL}$ creatine kinase), demembranated sperm chromatin $(1000 / \mu \mathrm{L})$, and egg lysis buffer (250 mM sucrose, $2.5 \mathrm{mM} \mathrm{MgCl}_{2}, 50 \mathrm{mM} \mathrm{KCl}, 1 \mathrm{mM}$ DTT, $10 \mathrm{mM}$ HEPES at $\mathrm{pH}$ 7.5). 


\section{Cloning of $x B L M$}

Two degenerate primers were used for the cloning of $x B L M$ : 5'-CGGGATCCTGGGGICAYGAYTTYMG-3' (upstream; translated from WGHDFR) and 5'-GGGGTACCDATICCCATICCRAANGC-3' (downstream; translated from ALTATA). The enzyme was AmpliTaq Gold (Perkin Elmer), and the template DNA was purified from a Xenopus oocyte lambda gt11 cDNA library. A touchdown protocol was used for PCR: $10 \mathrm{sec}$ at $94^{\circ} \mathrm{C}, 4 \mathrm{~min}$ at $47^{\circ} \mathrm{C}\left(-0.5^{\circ} \mathrm{C}\right.$ per cycle for 16 cycles and then $4 \mathrm{~min}$ at $37^{\circ} \mathrm{C}$ for 35 cycles), and $25 \mathrm{sec}$ at $72^{\circ} \mathrm{C}$. The carboxyl terminus was cloned by a $3^{\prime}$ RACE reaction from the same DNA template, whereas the amino terminus was cloned by 5 ' RACE from the total RNA isolated from oocytes.

Expression and purification of recombinant $x B L M$

The entire $x B L M$ gene was cloned between the NdeI and Xho I sites of expression vector pET-29b (Novagen). The recombinant xBLM expressed by $\mathrm{pET}-29 \mathrm{~b}$ vector has no additional amino acid added at the amino terminus and only two amino acids (from the Xhol site) plus six histidines at the carboxyl terminus. The recombinant XBLM was first purified on a HiTrap Chelating column (Pharmacia) following the procedure suggested by Novagen. The imidazole-eluted fractions containing recombinant xBLM were pooled and further purified on a Pharmacia HiTrap SP column. Specifically, the column was first washed with 40 column volumes of $400 \mathrm{mM} \mathrm{NaCl}$, then eluted with a linear gradient of $450 \mathrm{mM}$ to $650 \mathrm{mM} \mathrm{NaCl}$ in a buffer containing $25 \mathrm{mM}$ Tris- $\mathrm{HCl}(\mathrm{pH} 7.5), 1 \mathrm{mM}$ EDTA, 1 mM DTT, and 10\% glycerol. Typically, the recombinant xBLM was eluted in $500-600 \mathrm{mM} \mathrm{NaCl}$ fractions.

\section{DNA helicase assay}

The substrate for DNA helicase assays is a $5^{\prime}{ }^{32} \mathrm{P}$-labeled $48 \mathrm{mer}$ oligonucleotide hybridized to circular m13 single-stranded DNA. The xBLMHis protein was incubated with the substrate at the final concentration of $2 \mathrm{ng} / \mu \mathrm{L}$ and $0.8 \mathrm{ng} / \mu \mathrm{L}$, respectively, in egg lysis buffer. After $30 \mathrm{~min}$ at room temperature, the reactions were terminated by mixing with an equal volume of stop buffer (0.5\% SDS, $20 \mathrm{mM}$ EDTA) and separated on a $12 \%$ polyacrylamide/TAE gel.

\section{Antibody production and purification}

A glutathione $\mathrm{S}$ transferase (GST) fusion protein containing amino acids 1-671 of xBLM was purified from SDS-PAGE and then injected into rabbits. The resulting polyclonal antibodies were purified following the published procedure (Yan et al. 1993). Briefly, they were first purified on an affinity column of a GST fusion protein containing amino acids 1-173 of xBLM. The anti-GST antibodies were then removed by an affinity column of GST tag alone.

\section{Immunodepletion}

Immunodepletion was performed by incubating extracts (diluted twofold with egg lysis buffer) with Affi-gel Protein A beads (Bio-Rad) that had been precoated with either the affinity-purified rabbit anti-xBLM antibody or rabbit IgG. After $1 \mathrm{~h}$ at $4^{\circ} \mathrm{C}$, the beads were removed by low-speed centrifugation, and the supernatants were collected for replication assays. The efficiency of depletion was assessed by Western blot with the appropriate antibodies.

\section{Replication assays}

Radioactive assays of nuclear DNA replication were performed by including $\left[{ }^{32} \mathrm{P}\right] \mathrm{dATP}$ in reactions containing sperm chromatin and interphase extracts or reactions containing $\mathrm{m} 13$ single-stranded DNA and cytosol. Samples were taken at various time points, processed, and separated on 1\% agarose TAE gels as described previously (Smythe and Newport 1991). The dried gels were exposed to X-ray film and a PhosphorImager (Fuji). For visual assays of DNA replication, $10 \mu \mathrm{M}$ biotin-dCTP was added to the reaction and detected by Streptavidin-Texas Red (Calbiochem) following the published procedure (Yan and Newport 1995). The GenBank accession no. for xBLM is AF30784.

\section{Acknowledgments}

We thank Dr. Yoshihiro Matsumoto for providing the purified recombinant human $\mathrm{p} 21$ protein and Drs. John Taylor and Robert Perry for critically reading the manuscript. This work was supported by grants from the V Foundation, Ellison Medical Foundation, and National Institutes of
Health (R01 GM57962-02) to H.Y. and NIH training grant (CA-09035-25) to S.L.

The publication costs of this article were defrayed in part by payment of page charges. This article must therefore be hereby marked "advertisement" in accordance with 18 USC section 1734 solely to indicate this fact.

\section{References}

Chester, N., Kuo, F., Kozak, C., C.D. O'Hara, C.D., and Leder, P. 1998. Stage-specific apoptosis, developmental delay, and embryonic lethality in mice homozygous for a targeted disruption in the murine Bloom's syndrome gene. Genes \& Dev. 12: 3382-3393.

Courcelle, J. and Hanawalt, P.C. 1999. RecQ and RecJ process blocked replication forks prior to the resumption of replication in UV-irradiated Escherichia coli. Mol. Gen. Genet. 262: 543-551.

Ellis, N.A., Groden, J., Ye, T.Z., Straughen, J., Lennon, D.J., Ciocci, S. Proytcheva, M., and German, J. 1995. The Bloom's syndrome gene product is homologous to RecQ helicases. Cell 83: 655-666.

Friedberg, E.C., Ehmann, U.K., and Williams, J.I. 1979. Human diseases associated with DNA repair. Adv. Rad. Biol. 8: 85-174.

German, J. and Ellis, N.A. 1998. Bloom Syndrome. In The Genetic Basis of Human Cancer (ed. B. Vogelstein and K.W. Kinzler), pp. 301-315. McGraw-Hill, New York.

Hand, R. and German, J. 1975. A retarded rate of DNA chain growth in Bloom's syndrome. Proc. Nat1. Acad. Sci. 72: 758-762.

Ishov, A.M., Sotnikov, A.G., Negorev, D., Vladimirova, O.V., Neff, N., Kamitani, T., Yeh, E.T., Strauss, J.F. III, and Maul, G.G. 1999. PML is critical for ND10 formation and recruits the PML-interacting protein daxx to this nuclear structure when modified by SUMO-1. I. Cell Biol. 147: 221-234.

Jackson, P.K., Chevalier, S., Philippe, M., and Kirschner, M.W. 1995. Early events in DNA replication require cyclin E and are blocked by p21CIP1. J. Cell Biol. 130: 755-769.

Johnson, F.B., Lombard, D.B., Neff, N.F., Mastrangelo, M.A., Dewolf, W., Ellis, N.A., Marciniak, R.A., Yin, Y., Jaenisch, R., and Guarente, L. 2000. Association of the Bloom syndrome protein with topoisomerase III $\alpha$ in somatic and meiotic cells. Cancer Res. 60: 1162-1167.

Karow, J.K., Chakraverty, R.K., and Hickson, I.D. 1997. The Bloom's syndrome gene product is a $3^{\prime}-5^{\prime}$ DNA helicase. J. Biol. Chem. 272: 30611-30614.

Lebel, M., Spillare, E.A., Harris, C.C., and Leder, P. 1999. The Werner syndrome gene product co-purifies with the DNA replication complex and interacts with PCNA and topoisomerase I. J. Biol. Chem. 274: 37795-37799.

Lee, S.K., Johnson, R.E., Yu, S.L., Prakash, L., and Prakash, S. 1999. Requirement of yeast $S G S 1$ and $S R S 2$ genes for replication and transcription. Science 286: 2339-2342.

Lohka, M.J. and Masui, Y. 1983. Formation in vitro of sperm pronuclei and mitotic chromosomes induced by amphibian ooplasmic components. Science 220: 719-721.

Lonn, U., Lonn, S., Nylen, U., Winblad, G., and German, J. 1990. An abnormal profile of DNA replication intermediates in Bloom's syndrome. Cancer Res. 50: 3141-3145.

Mechali, M. and Harland, R.M. 1982. DNA synthesis in a cell-free system from Xenopus eggs: Priming and elongation on single-stranded DNA in vitro. Cell 30: 93-101.

Murray, J.M., Lindsay, H.D., Munday, C.A., and Carr, A.M. 1997. Role of Schizosaccharomyces pombe RecQ homolog, recombination, and checkpoint genes in UV damage tolerance. Mol. Cell. Biol. 17: 68686875.

Neff, N.F., Ellis, N.A., Ye, T.Z., Noonan, J., Huang, K., Sanz, M., and Proytcheva, M. 1999. The DNA helicase activity of BLM is necessary for the correction of the genomic instability of bloom syndrome cells. Mol. Biol. Cell 10: 665-676.

Newport, J. 1987. Nuclear reconstitution in vitro: Stages of assembly around protein-free DNA. Cell 48: 205-217.

Ray, J.H. and German, J. 1983. The cytogenetics of the chromosomebreakage syndromes. In Chromosome Mutation and Neoplasia (ed. J. German), pp. 135-167. Alan R. Liss, New York.

Schellenberg, G.D., Miki, T., Yu, C.E., and Nakura, J. 1998. Werner Syndrome. In The Genetic Basis of Human Cancer (ed. B. Vogelstein and K.W. Kinzler), pp. 347-359. McGraw-Hill, New York. 
Smythe, C. and Newport, J.W. 1991. Systems for the study of nuclear assembly, DNA replication, and nuclear breakdown in Xenopus laevis egg extracts. Meth. Cell Biol. 35: 449-468.

Stewart, E., Chapman, C.R., Al-Khodairy, F., Carr, A.M., and Enoch, T. 1997. rqh1+, a fission yeast gene related to the Bloom's and Werner's syndrome genes, is required for reversible $\mathrm{S}$ phase arrest. $E M B O T$. 16: $2682-2692$

Strausfeld, U.P., Howell, M., Rempel, R., Maller, J.L., Hunt, T., and Blow, J.J. 1994. Cip1 blocks the initiation of DNA replication in Xenopus extracts by inhibition of cyclin-dependent kinases. Curr. Biol. 4: 876883.

Wang, Y., Cortez, D., Yazdi, P., Neff, N., Elledge, S.J., and Qin, J. 2000. BASC, a super complex of BRCA1-associated proteins involved in the recognition and repair of aberrant DNA structures. Genes \& Dev. 14: 927-939.

Wu, L., Davies, S.L., North, P.S., Goulaouic, H., Riou, J.F., Turley, H., Gatter, K.C., and Hickson, I.D. 2000. The Bloom's syndrome gene product interacts with topoisomerase III. J. Biol. Chem. 275: 96369644.

Yan, H. and Newport, J. 1995. An analysis of the regulation of DNA synthesis by cdk2, Cip1, and licensing factor. J. Cell Biol. 129: 1-15.

Yan, H., Merchant, A.M., and Tye, B.K. 1993. Cell cycle-regulated nuclear localization of MCM2 and MCM3, which are required for the initiation of DNA synthesis at chromosomal replication origins in yeast. Genes \& Dev. 7: 2149-2160.

Yan, H., Chen, C.Y., Kobayashi, R., and Newport, J. 1998. Replication focus-forming activity 1 and the Werner syndrome gene product [see comments]. Nat. Genet. 19: 375-378.

Yankiwski, V., Marciniak, R.A., Guarente, L., and Neff, N.F. 2000 Nuclear structure in normal and bloom syndrome cells. Proc. Nat1. Acad. Sci. 97: 5214-5219.

Zhong, S., Hu, P., Ye, T.Z., Stan, R., Ellis, N.A., and Pandolfi, P.P. 1999. A role for PML and the nuclear body in genomic stability. Oncogene 18: 7941-7947. 


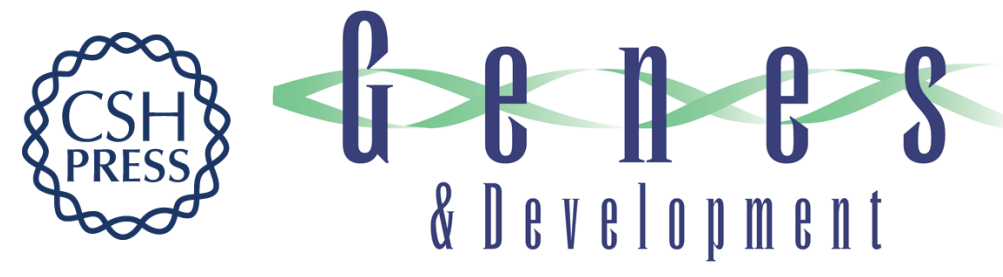

\section{The function of Xenopus Bloom's syndrome protein homolog (xBLM) in DNA replication}

Shuren Liao, Jeanine Graham and Hong Yan

Genes Dev. 2000, 14:

Access the most recent version at doi:10.1101/gad.822400

References This article cites 27 articles, 18 of which can be accessed free at: http://genesdev.cshlp.org/content/14/20/2570.full.html\#ref-list-1

License

Email Alerting

Receive free email alerts when new articles cite this article - sign up in the box at the top Service right corner of the article or click here.

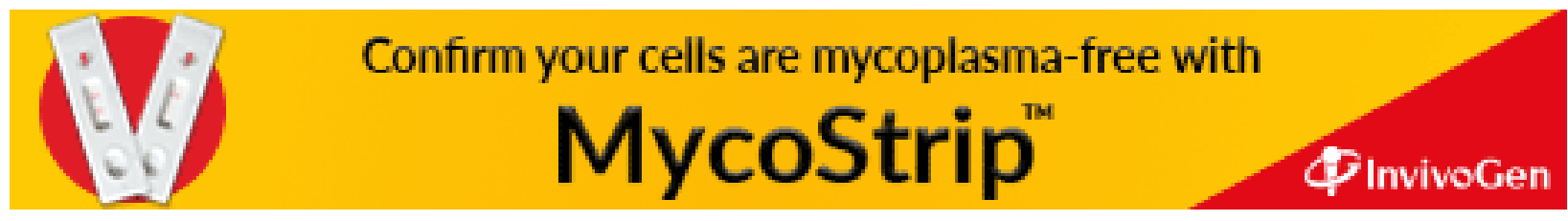

